\title{
Internally displaced persons and health effects caused by the floods that affected Romania during 2006-2007
}

Univ. Assist. Anca Magdalena MUNTEANU ${ }^{1,2}, \mathrm{MD}, \mathrm{PhD}$, Adriana PISTOL ${ }^{1}, \mathrm{MD}$, PhD, Loreta GUJA ${ }^{2}, \mathrm{MD}$, Simona CARNICIU ${ }^{4}, \mathrm{MD}$, PhD, Lecturer Dana POPESCU-SPINENI ${ }^{2,3}, \mathrm{MD}, \mathrm{PhD}$, Assoc. Prof. Anca Maria MOLDOVEANU², MD, PhD

${ }^{1}$ National Institute of Public Health

2"Carol Davila" University of Medicine and Pharmacy, Bucharest ${ }^{3}$ Institute of Anthropology "Fr. I. Rainer" of the Romanian Academy, Bucharest 4"Corposana" Center for Research in Diabetes and Nutrition Disorders, Bucharest

\begin{abstract}
The heavy rainfall between late 2005 and early 2006 in South Romania caused severe flooding, as to environmental, social and economic consequences. The event was unique in the last 3 decades in Romania, and among the most severe flooding events in the WHO-European region, in the last decade, next to the floods registered in Rusia, Turkey and Great Britain. Large household damages, requiring internal displacement of persons, part of which being sheltered in camps, for up to 17 months occured in 6 counties, 5 of them located along the Danube river and 1 county in the hill-mountain region. Our study aimed to quantify people displacement, camp sheltering and morbidity profile among the sheltered people, during the existence of the camps. We present an observational study, using data collected by the surveillance system that ran in the affected territory, under the management of the National Institute of Public Health. The calculated values of the target indicators showed the following results: people displacement rate of 316 $\% 000$ inhabitants, camp sheltering rate of $100 \% 000$ inhabitants; sheltering in tents represented $84 \%$, for 2-25 weeks, of the total 68 weeks. "Communicable diseases" was the diagnosis category registered in each of the 6 counties, representing less than 30\% of all the diagnosis categories. The category "injuries" did not exceed 5\%, in 5 of the 6 counties, while "psychological trauma" did not exceed 1.2\%, in only 3 of the 6 counties. The acute respiratory infections, of upper tract, followed by those of lower tract contributed more than $85 \%$ to all communicable disesses. Acute eye inflamations, acute watery diarrhoea, other rushes than measles and pediculosis contributed each less than 5\%. Only 2 cases of clinical measles and 1 case of scab were registered. Most of the communicable diseases occured in children and adults. Neither death, nor disease outbreak were registered.

Conclusions. The flood event generated internally displaced persons, some of which needed shelter in long term camps. Tents were the preponderant category of shelters. The communicable diseases, injuries and psychological trauma were not prevailing categories among the camp sheltered persons. The acute respiratory infections were preponderant among infections. Neither deaths, nor disease outbreaks occurred for the duration of camps.
\end{abstract}

Keywords: floods, Danube river, internally displaced persons, long term camps, communicable diseases, injuries, psychological trauma 


\section{INTRODUCTION}

The human activities based on fossil fuel burning during the last 5 decades have been generated greenhouse gases, responsible for the increasing global warming. Among consequences are the extreme weather events, more intense, more frequent, affecting larger areas, including the temperate climate regions: heat waves, wild fires and droughts, on one side, heavy rainfalls, floods, landslides, violent landstorms and cyclones, on the other side. Climate changes affects major social and environmental determinants of health, such as availability and quality of drinking water, ecosystems, agriculture and food production, economic development and population migration (41). Globally, the natural disasters related to climate changes, registered after 1960 increased 3 times, causing 60,000 deaths. The WHO estimation for 20302050 is not at all optimistic: 250,000 deaths per year, of which 38,000 through heat waves, 48,000 through diarrhoea, 60,000 through malaria and 95,000 through infant malnutrition $(39,43)$. As to the WHO European Region, between 1990 and 2012 there have been registered: 40 drought events, 121 earthquake, 222 extreme temperature, 491 floods, 2 insect infestation, 5 mass movement dry, 57 mass movement wet, 333 storms, 4 volcano and 82 wild fires.

The above mentioned floods caused 4,568 deaths, affected $12,800,073$ people and caused an economic damage (thousands of US\$) of $94,410,590$ (40). The estimation for the next decades in Europe shows increasing precipitation, soil erosion and flooding (1), that, without adaptation, might lead to an increasing number of European people potentially affected by flooding, every year by 2085 , from 775,000 to 5.5 million (10). The short term health risks when exposed to heavy rainfall and flooding are deaths (by drowning), infections (water, food and vector borne), injuries and psychiatric trauma. The risk of infection is high in important population displacement and/or compromised water sources. It occurs typhoid fever, cholera, hepatitis A (through unsafe water consumption), as well as leptospirosis, wound infections, dermatitis, conjunctivitis, and ear, nose and throat infections (through direct contact with polluted waters). In flooding, the expansion in the number and range of vector habitats also occurs, causing an increase of vector-borne human diseases: malaria, dengue and dengue haemorrhagic fever, yellow fever, and West Nile
Fever. Workers who routinely handle corpses may have a risk of contracting tuberculosis, bloodborne viruses (such as hepatitis B/C and $\mathrm{HIV}$ ), and gastrointestinal infections (such as rotavirus diarrhoea, salmonellosis, E. coli, typhoid/paratyphoid fevers, hepatitis $A$, shigellosis and cholera). Respiratory infections, measles, pediculosis or scab might also occure, in conditions of high density of habitation and inssufficient sanitation and personal hygiene. Such health risks are amplified by the possible diminished access to healthcare services in floodings (damaged access routes and/or healthcare units) $(6-8,38,45)$.

People migration is another major effect in natural disasters or conflicts. Globally, between 2008 and 2014, 1 person per second have been displaced (17). Migration in defined in terms of duration and distance of movement from the native place. It is used "short term migration", for less than 1 year, or "long term migration", for duration more than 1 year. It is used "internal displacement", inside a country's borders and "international migration" when people migration crosses the borders. "Internal displacement" occurs most frequently in natural disasters ("environmental migrants"), "international migration" in conflicts and wars ("international migrants") $(5,37)$. Internally Displaced Persons (IDP), are defined as "persons or groups of persons who have been forced or obliged to flee or to leave their homes or places of habitual residence, as a result of ...natural or human-made disasters, and who have not crossed an internationally recognized state border" (19). Floods generate effects of high to medium severity, in comparison to other naturale disasters (38).

During the last decades, Romania was the most frequently affected by heat waves, followed by intense precipitation causing flooding and landslides. The most important flooding event occured after the heavy rainfall between the late 2005 and the early 2006, affecting 11 counties of the southern part of the country: 10 counties located in the plain of the river Danube - Braila (BR), Calarasi (CL), Constanta (CT), Dolj (DJ), Giurgiu (GR), Ialomita (IL), Mehedinti (MH), Olt(OT), Tulcea (TL) and Teleorman (TR) and 1 county, Gorj (GJ), situated in a hill-mountain area, crossed by an important affluent of the Danube. There have been registered a lot of damaged to destroyed households, internally displaced people (IDP), part of them sheltered in camps. For the local government authorities the event was challenging, as to ensuring shel- 
tering, water and food supplies, sanitation and hygiene, vector control, under the recomandations of the public health authorities, guided by specific provisions $(31,35,42,46,47,50,52)$. The public health authorities elaborated plans and run the actions of: health state surveillance of the persons sheltered in camps, monitoring the quality of food and drinking water, waste management, vector control, health education, vaccination $(4,18,23,25,30,48,49,51)$. Priority was given to vaccinations against measles, mumps, rubella, diphtheria, tetanus, pertussis, Haemophilus influenzae tip $B$ infections, $B$ virus hepatitis, meningococcal disease, pneumococcal disease, varicella, influenza, tuberculosis $(4,11)$. The decisions with regard to the site selection, the arrangement of emergency settlements and the living conditions in such settlements were guided by global references $(3,12,28,34)$.

The aim of our study was to quantify and describe: internal displacement of persons, camp sheltering, addressability to healthcare services in camps, morbidity and mortality in camps.

\section{METHOD AND MATERIALS}

We ran an observational study of the internal displacement of persons, habitation conditions, morbidity and mortality in camps that functioned for up to 17 months (may 2006 september 2007) on the territory of 6 of the 11 counties affected by flooding (Braila, Calarasi, Constanta, Dolj, Tulcea) or landslides (Gorj). In each camp the local public health authorities surveilled the health state of sheltered persons and monitored the hygiene and sanitation conditions, under the coordination of the National Institute of Public Health (NIPH). We used weekly generated data, related to: urban and rural affected localities, number of displaced persons, of which number of camp sheltered, by type of shelters: tent $(T)$, building (B), pontoon $(P)$, number of camp sheltered persons who addressed primary healthcare services attributed to the camps, total and by 4 diagnosis categories: "communicable disease" (CD), "injury" (INJ), "psychological trauma" (PSY TR) and "other diagnosis" (OTH). In the category "communicable disease", the clinicians ran diagnosis for 15 syndromes recommended by WHO to be surveilled in human communities affected by natural disasters or conflicts/wars: acute respiratory infections of upper respiratory tract (ARIUT), acute respiratory infections of lower respiratory tract (ARILT), acute eye inflamation (AEI), acute watery diarrhoea (WD), acute bloody diarrhoea $(B D)$, measles (MEA), other rushes (RSH), pediculosis (PED), scab (SCB), meningitis/encephalitis (MGE), acute jaundice syndrome (AJS), unknown origin fever (UF), cluster of unknown disease (CUD), influenza (FLU), cholera (CHL). There have been registered the possible cases, according to the case definitions $(4,9,15,18,23$, 25). Data served to compute the following indicators: displacement rate, camp sheltering rate, density of habitation in tents, buildings or pontoons, people addressability to primary healthcare services in camps, diagnosis categories profile, communicable diseases profile, atack rates by communicable diseases, specific mortality in camps.

\section{RESULTS}

In may 2006 we registered the highest number $(9,000)$ of internally displaced persons, from 6 of the 11 affected counties, with a weekly dynamic showed in Fig. 1 . The displacement rate in the territory was 300 persons $\% 000$ inhabitants, from 42 localities, 37 rural (88\%) and only 5 urban (12\%). The values by county are shown in Table 1. Camp sheltering in the territory was $37 \%$ of the displaced, at a rate of sheltering of 121 persons $\% 000$ inhabitants. The weekly dynamic of the number of persons sheltered in camps is shown in Fig. 1, too. The county levels of sheltering indicators are shown in Table 2. The duration of camps ranged 4-68 weeks (1-17 months), depending on county (Table 2). Camp shelters profile showed $84 \%$ tents, $15 \%$ buildings, $1 \%$ pontoons (in TL county only). The density of habitation resulted of 17 people/pontoon, 12 people/tent and 7 people/building. Details by county are shown in Table 3 .

TABLE 1. Displacement: frequency and spread

\begin{tabular}{|c|c|c|c|c|}
\hline \multirow{2}{*}{ county } & \multirow{2}{*}{$\begin{array}{c}\text { no. of } \\
\text { displaced }\end{array}$} & \multirow{2}{*}{$\begin{array}{c}\text { displaced } \\
\text { rate (\%000 } \\
\text { inhabitants) }\end{array}$} & \multicolumn{2}{|c|}{$\begin{array}{c}\text { no. of localities } \\
\text { with displacement }\end{array}$} \\
\hline & & & rural & urban \\
\hline $\mathrm{CL}$ & 2,693 & 863 & 8 & 1 \\
\hline DJ & 4,494 & 640 & 6 & 0 \\
\hline $\mathrm{TL}$ & 777 & 316 & 7 & 1 \\
\hline GJ & 510 & 136 & 1 & 0 \\
\hline CT & 360 & 50 & 15 & 2 \\
\hline BR & 98 & 27 & 0 & 1 \\
\hline TOTAL & 8,932 & 329 & 37 & 5 \\
\hline
\end{tabular}


no. inhabitants

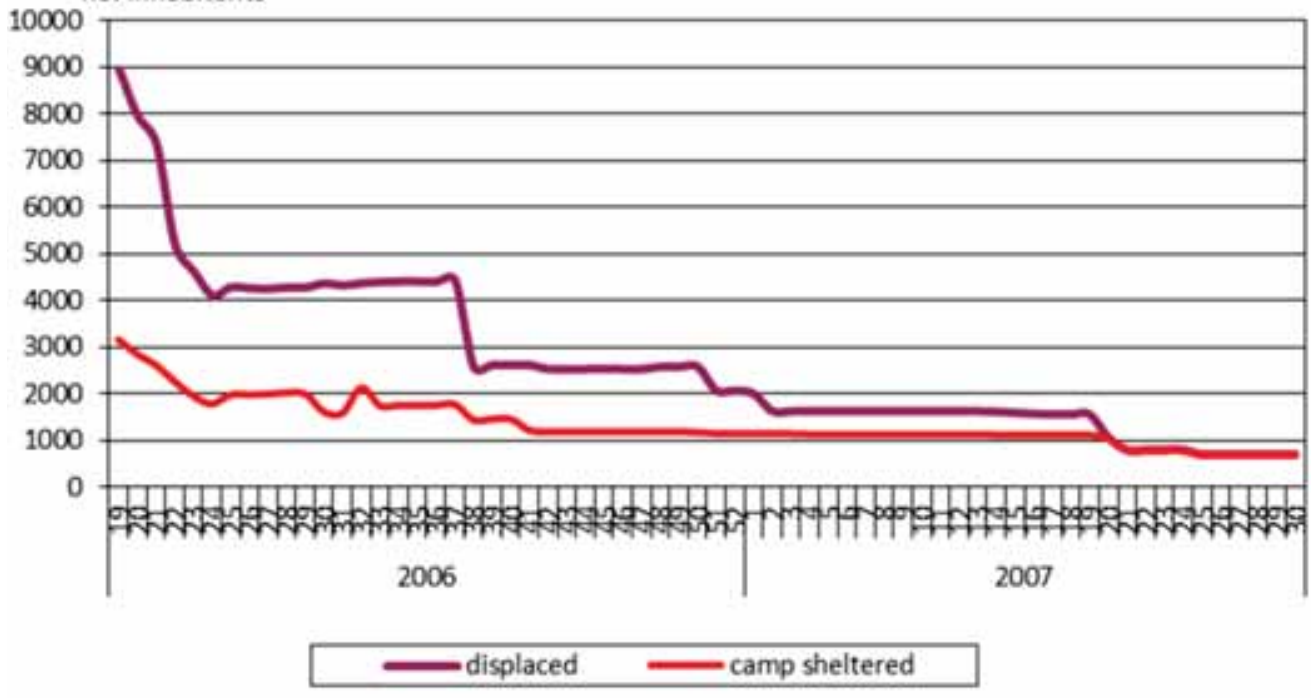

FIGURE 1. Weekly dynamics of the displaced and camp sheltered people. Romania, flooding, 2006-2007

TABLE 2. Displacement, sheltering in camps and duration of camps

\begin{tabular}{|c|c|c|c|c|c|}
\hline \multirow{2}{*}{ county } & \multirow{2}{*}{$\begin{array}{c}\text { no. of } \\
\text { displaced }\end{array}$} & \multirow{2}{*}{ \% sheltered } & \multicolumn{2}{|c|}{ rates (\%000 inhabitants) } & \multirow{2}{*}{$\begin{array}{c}\text { camps duration } \\
\text { (weeks) }\end{array}$} \\
\cline { 4 - 5 } & & displaced & sheltered & 63 \\
\hline CL & 2,693 & 46 & 863 & 395 & 63 \\
\hline DJ & 4,494 & 35 & 640 & 226 & 35 \\
\hline GJ & 777 & 8 & 316 & 26 & 32 \\
\hline CT & 510 & 54 & 136 & 73 & 68 \\
\hline BR & 360 & 22 & 50 & 11 & 4 \\
\hline TOTAL & $\mathbf{8 , 9 3 2}$ & 54 & 27 & 15 & \\
\hline
\end{tabular}

TABLE 3. Sheltering conditions in camps

\begin{tabular}{|c|c|c|c|c|c|c|c|}
\hline \multirow{2}{*}{ county } & \multicolumn{3}{|c|}{ shelter type (\%) } & \multicolumn{3}{c|}{$\begin{array}{c}\text { habitation density } \\
\text { (no. people/shelter) }\end{array}$} & $\begin{array}{c}\text { habitation in } \\
\text { tents } \\
\text { (no. weeks) }\end{array}$ \\
\cline { 2 - 7 } & B & T & P & B & T & P & 0 \\
\hline BR & 100 & 0 & 0 & 53 & 0 & 0 & 20 \\
\hline CL & 0.6 & 99.4 & 0 & 43 & 7 & 0 & 25 \\
\hline CT & 96.4 & 0.6 & 0 & 1 & 2 & 0 & 12 \\
\hline DJ & 61.5 & 38.5 & 0 & 22 & 283 & 0 & 2 \\
\hline GJ & 42.6 & 57.4 & 0 & 6 & 1 & 0 & 25 \\
\hline TL & 18.2 & 63.6 & 18.2 & 4 & 3 & 17 & \\
\hline TOTAL & 15 & 84 & 1 & 7 & 12 & 17 & \\
\hline
\end{tabular}

Weekly adressability to primary healthcare servicies organized in camps ranged largely $5-80 \%$, peaking during the first 2 months (Table 4). The morbidity profile in camps, territory level: $90.9 \%$ "other diagnoses", 7\% "communicable diseases", $2 \%$ "injuries" and $0.1 \%$ "psychological trauma", details by county in Fig. 2. ARIUT, followed by ARILT, contributed $85 \%$ of the communicable diseases. Other infectious syndromes, each less then $5 \%$ contribution, were: $A E I, W D$, RSH, PED, MEA and SCB (Fig. 3). The communicable diseases by age groups is shown in Fig. 4 and by county in Table 5 . The atack rates by communicable diseases peaked the first 6 weeks and ranged as follows: ARIUT 6\% (CL) $-60 \%$ (GJ); ARILT $0.7 \%(C L)-10 \%(C T) ;$ AEI $0.4 \%$ (DJ) $-7.5 \%$ (CT); WD 0.7\% (CL) - 0.9\% (GJ); MEA 35\% (CL); RSH 0.7\% (CL) - 9\% (CT); PED 0.4\% (CL) $4 \%$ (BR); SCB $0.4 \%$ (GJ). Along the maximum duration of camps no case of influenza, acute bloody diarrhoea, meningitis/encephalitis, acute jaundice syndrome, unknown origin fever, cluster of unknown disease or cholera was registered. Neither disease outbreak, nor deaths were registered in camps. 


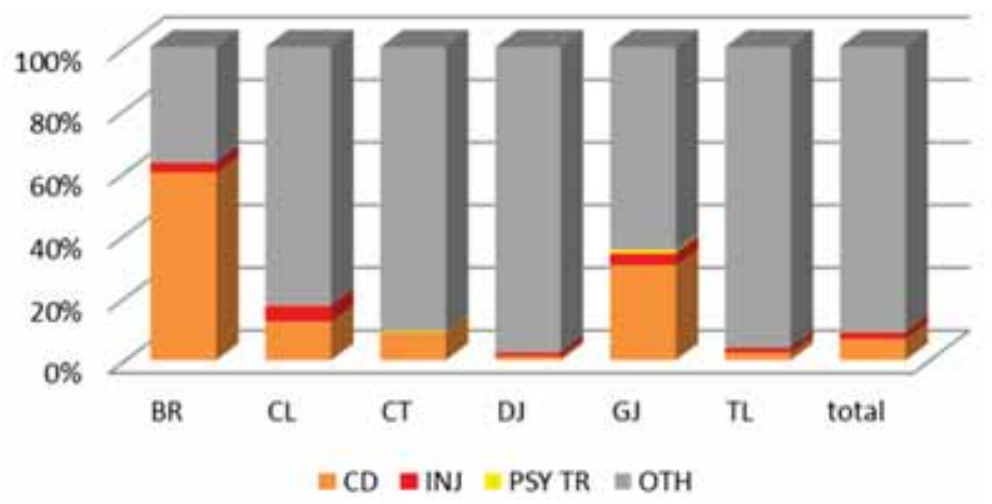

FIGURE 2. The morbidity profile in camps. Romania, flooding, 2006-2007

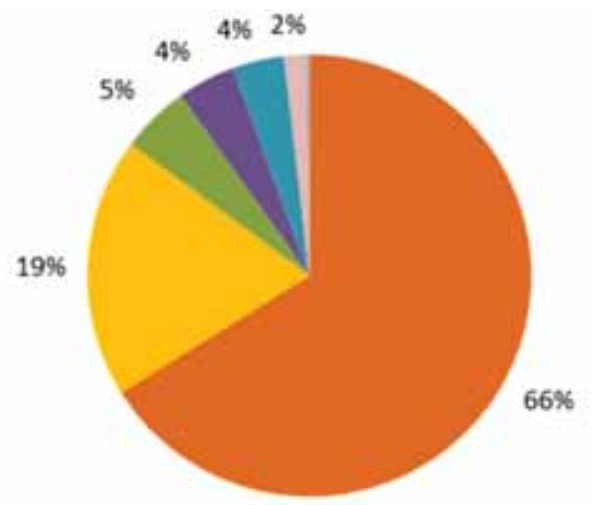

$\approx A R I U T=A R I T=A E I \equiv W D=R S H=P D C=M E A=S C B$

FIGURE 3. Communicable diseases profile in camps. Romania, flooding, 2006-2007

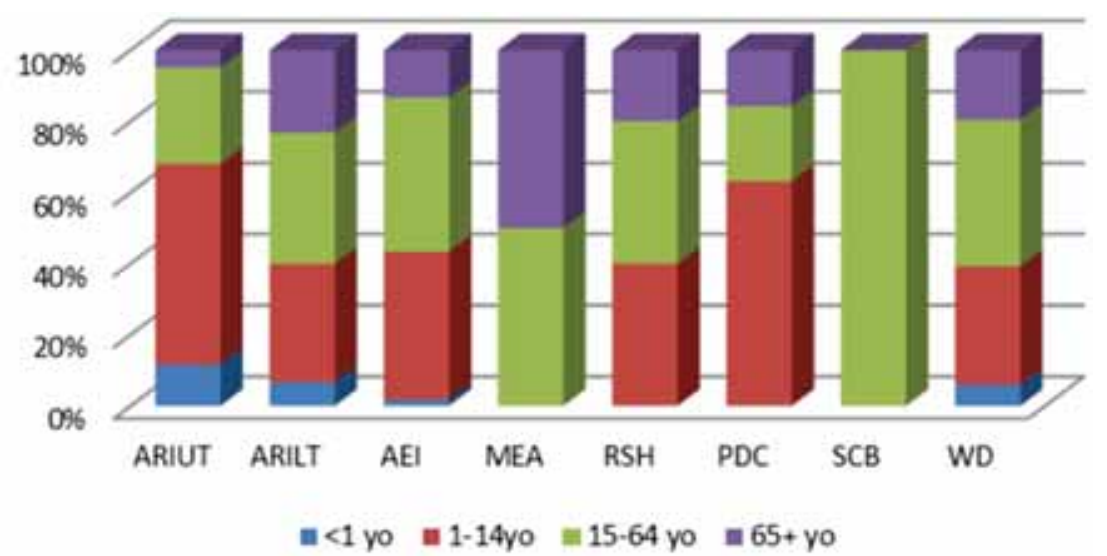

FIGURE 4. Communicable diseases by age group in camps. Romania, flooding, 2006-2007

TABLE 4. Weekly addressability to primary healthcare services in camps

\begin{tabular}{|c|c|c|}
\hline county & $\begin{array}{c}\text { addressability (\%), } \\
\text { range }\end{array}$ & peaking week \\
\hline BR & $7-25$ & S2 \\
\hline CL & $10-35$ & S1, S4 \\
\hline CT & $5-50$ & S4 \\
\hline DJ & $5-50$ & S5 \\
\hline GJ & $10-80$ & S2 \\
\hline TL & $14-31$ & S2, S5, S10 \\
\hline
\end{tabular}

\section{DISCUSSIONS}

Among the countries of the WHO European Region, Romania was the most affected by heavy rainfall and flooding, after Rusia, during the first decade of the $21^{\text {st }}$ century, at a rate of "affected" persons ranging 5,000-10,000 per milion inhabitants (20). Our "displacement" rate (3,000 per million inhabitants) converges to the above data, considering "affected" is always 
more than "displaced" persons, in any flooding event. More than this, in 2 of the 6 counties where camps had to be organized, the displacement rate overcame the territory level: 3 times more in $\mathrm{CL}$ (8,630 per million inhabitants) and 2 times more in DJ $(6,400$ per million inhabitants) (Table 1).

Yet, have to say that the severity of this flooding event in Romania was relative, comparing to other recent flooding events all over the world: the april 2017 floods in Peru led to 1.3 million people affected and over 42,000 collapsed houses, 136 deaths and 18 missing people $(24,32)$.

Rural habitation areas were far more affected by displacement than the urban ones. The ratio urban: rural localities with IDP was 7:1 (Table 1). CT county registered the highest number (15) of rural localities with IDP. In most of the other counties, 6-8 rural localities were affected by IDP. As to the urban localities with IDP, it was almost expectable a much lower level: no locality to 2 localities per county. It is obvious that the WHO vulnerability criteria were met in rural much more than in urban areas $(2,5,38,44)$. In rural areas prevailed the river floods, while in the urban areas the flash floods, but nowhere was the case of coastal floods, as in at risk coastal cities of the world (Cairo, Calcutta, Delhi, Dhaka, Lagos, Manila, New York, Rio de Janeiro, Sao Paulo, Shanghai) (38). Three thousand of the IDP (37\%) needed to be sheltered in camps by the local government authorities, as a consequence of 2 aspects: their households were severely damaged, while they found no shelter at their relatives or friends. In 3 of the 6 affected counties the percentage of IDP sheltered in camps overcame the territory level: GJ (54\%), BR (54\%) and CL (46\%). Half of the affected territory registered "long term" camps, that is more than 52 weeks $(19,37)$ : CT 68 weeks, CL and DJ, 63 weeks each (Table 2). The duration of the camps' operation depended on the economic and organizational capacities of the authorities to ensure permanent and safe new habitation conditions. Tent as shelter represented $99 \%$ of the habitation forms in CL camps, $64 \%$ in TL camps and $57 \%$ in GJ camps. The duration of sheltering in tents lasted up to 25 weeks in CT and TL (Table 3). Under the registered addressability to primary healthcare services in camps (Table 4), the morbidity was dominated by the category "other diagnoses" in 5 of 6 counties. The category "communicable diseases" prevailed in BR county only (60\%). In rest, it did not exceed $31 \%$ contribution along the categories. "Injuries" contributed with less than $5 \%$, in 5 of the 6 counties (less CT). "Psychological trauma" was a diagnosis category registered in 3 of 6 counties (CL $0.1 \%$, CT $0.3 \%$, GJ 1.2\%), contributing along the categories with less than $1.2 \%$ (Fig. 2). Recent studies show psychological trauma to have an important contribution to the pathologies related to flooding, in the chronic phase, especially in high income population $(14,29)$. When appears in the acute phase of the flooding, it is associated with displacement, may persist 6 months to 1 year and may have chronic evolution. The lack of the awareness or of the efficacy of the awareness was found negative influence factor associated with psychological trauma $(22,26)$.

Tackling the awareness in floooding related to health, a prestigious author shows there are enough theoretically measures to prevent and limit the effects of floods. What is deficient in varying degrees from one state to another is their implementation (13). More results are expected from the provisions of the Sendai Framework for Disaster Risk Reduction 2015-2030, that outcame from The Third UN World Conference on Disaster Risk Reduction, March 2015, Sendai City, Japan (36). The Environmental Emergencies Guidelines, $2^{\text {nd }}$ edition is also an instrument for action, full of value (33).

As to the communicable diseases profile in camps:

- ARIUT: contributed $66 \%$ at the territory level, were registered in every county, ranging $45-80 \%$; contribution that overcame the territory level were registered in 3 of the 6 counties (BR, TL, GJ);

- ARILT: contributed $19 \%$ at the territory level, were registered in every county, ranging 9-39\%; contribution that overcame the territory level were registered in 3 of the 6 counties (DJ, GJ, TL);

- AEI: contributed 5\% at the territory level, were registered in 4 of the 6 counties, ranging $1-10 \%$; contribution that overcame the territory level were registered in 3 of the 4 counties (CL, CT, DJ);

- WD: contributed $4 \%$ at the territory level, were registered in 4 of the 6 counties, ranging 2-8\%; contribution that overcame the territory level were registered in 2 of the 4 counties $(C L, T L)$;

- $R S H$ : contributed $4 \%$ at the territory level, were registered in 4 of the 6 counties, ranging $1-18 \%$; contribution that over- 
came the territory level were registered in 2 of the 4 counties (CL, CT);

- PED: contributed $2 \%$ at the territory level, were registered in 4 of the 6 counties, ranging 1-10\%; contribution that overcame the territory level were registered in 3 of the 4 counties ( $B R, C L, D J)$;

- For $M E A$, we registered 2 possible cases $(C L)$, while for $S C B$, a single case (GJ). (Table 5 and Fig. 3 ).

The age group "1-14 yo" had a prevailing contribution to the following infectious diagnoses: ARIUT (63\%), PED (55\%), AEI (38\%), RSH (33\%), WD (32\%), while the age group "15-64 yo" had a prevailing contribution to SCB (100\%). One MEA case was registered at "15-64 yo" age group, and the second case at "65+yo". Infant ages contributions in communicable diseases diagnoses showed: 10\% ARIUT, 5.4\% ARILT, 2.3\% WD and $0.9 \%$ AEI (Fig. 4).

Seven of the 15 surveilled infectious syndromes (46\%) were not registered during the whole duration of the camps: acute bloody diarrhoea (BD), meningitis/encephalitis (MGE), acute jaundice syndrome (AJS), unknown origin fever (UF), cluster of unknown disease (CUD), influenza (FLU), cholera ( $\mathrm{CHL}$ ). Neither disease outbreak, nor mortality were registerded.

Overcrowding alone, or combined with poor personal hygiene in camps is contributing factor in diseases such measles, varicella, influenza, meningitis and septicemia with meningococcus. Diseases transmitted by fleas and lice are not rare in such conditions, too, in camps. Recent izolated cases of recurrent fever were reported in the Netherlands, Germany, Finland and Belgium among migrants in Eritrea, Somalia and Sudan $(11,38)$. In our camps, while measles and pediculosis had very low contribution to the "communicable diseases" category of diagnosis, the acute respiratory infections had the highest contribution. Overcrowding has to be considered for them, too. A limit of our study is the lack of data referring "the habitation surface", that would have allowed us to express the density of habitation using "number of square meters/person" and not "number of persons per tent, building or pontoon", in order to better quantify "overcrowding".

Huge human displacement, as because of wars, generates important mortality $(60-80 \%)$ during the first weeks from the onset, by measles, acute respiratory infections and malaria, in population previously affected of different forms of malnutrition: protein- calorie malnutrition, beriberi, pellagra, severe iron deficiency anemia, rachitis $(11,34,41)$. On one hand, Romania did not face huge human displacement, on the other, the persons displaced and sheltered in camps did not suffer of previous important degree of malnutrition. If we add the consistent interventions of the public health authorities for water and food safety, for personal hygiene and sanitation, for vector control as well as for health education in camps, then the lack of mortality, the modest contribution of communicable diseases to the diagnoses profile in camps, even the infections profile become explicable.

\section{CONCLUSIONS}

It was a flooding event that imposed internally dispalcement of persons, an important part of them needing sheltering in camps for long term, mostly in tents. Neither communica-

TABLE 5. Communicable diseases profile (\%) in camps, by county

\begin{tabular}{|c|c|c|c|c|c|c|c|c|c|c|c|}
\hline \multicolumn{2}{|c|}{ BR } & \multicolumn{2}{c|}{ CL } & \multicolumn{2}{c|}{ CT } & \multicolumn{2}{c|}{ DJ } & \multicolumn{2}{c|}{ GJ } & \multicolumn{3}{c|}{ TL } \\
\hline ARIUT & 80 & ARIUT & 64 & ARIUT & 55 & ARIUT & 45 & ARIUT & 72 & ARIUT & 74 \\
\hline ARILT & 10 & AEI & 10 & ARILT & 18 & ARILT & 39 & ARILT & 24 & ARILT & 19 \\
\hline PDC & 10 & ARILT & 9 & RSH & 18 & AEI & 10 & WD & 2 & WD & 5 \\
\hline & & WD & 8 & AEI & 9 & WD & 3 & RSH & 1 & RSH & 2 \\
\hline & & RSH & 6 & & & PDC & 3 & AEI & 1 & & \\
\hline & & PDC & 3 & & & & & PDC & 1 & & \\
\hline & & & $* *$ & & & & & & $*$ & & \\
\hline & & & & & & & & & & & \\
\hline & & & & & & & & & & & \\
\hline
\end{tabular}

$* *=2$ MEA cases 
ble diseases, nor injuries or psychological trauma had major contributions to the diagnoses profile in camps; however infections ranked the second place, injuries the third place, while psychological trauma the last place. Acut respiratory infections dominated the profile of infections, in children and adult ages.

\section{Acknowledgements}

The authors express respectful thanks to all the local, regional and national public health workers involved in this event, whose every day professional efforts, for 17 months, contributed to make this article become possible.

\section{REFERENCES}

1. Alcamo J. et al. Europe. Climate change 2007: impacts, adaptation and vulnerability. In: Parry M.L. et al., eds. Contribution of working group II to the Fourth Assessment Report of the Intergovernmental Panel on Climate Change. Cambridge, Cambridge University Press, 2007;

2. Anderson M. (1995). Vulnerability to disaster and sustainable development: a general framework for assessing vulnerability. In: Munasinghe M, Clarke C, eds. Disaster prevention for sustainable development. Washington, DC, World Bank;

3. Assar M. (1971). Guide to sanitation in natural disasters. Geneva, World Health Organization;

4. Benenson A. (1995). Control of communicable diseases in man, 16th ed. Washington, DC, American Public Health Association;

5. Black Richard. 2001. Environmental Refugees: Myth or Reality? New Issues in Refugee Research Working Paper 34. Geneva: UN High Commissioner for Refugees;

6. Centers for Disease Control and Prevention. Climate and Health. Food and Waterborne Diarrheal Disease, https://www. cdc.gov/climateandhealth/effects/food_ waterborne.htm;

7. Centers for Disease Control and Prevention. Climate and Health. Mental Health and Stress-Related Disorders, https://www.cdc.gov/climateandhealth/ effects/mental_health_disorders.htm;

8. Centers for Disease Control and Prevention. Climate and Health. Precipitation Extremes: Heavy Rainfall, Flooding, and Droughts, https://www.cdc. gov/climateandhealth/effects/precipitation extremes.htm;

9. Centers for Disease Control and Prevention (1992). Famine-affected, refugee, and displaced populations: recommendations for public health issues. MMWR, 1992, 41(RR-13): 1-76. Atlanta, GA;

10. Ciscar et al. Physical and economic consequences of climate change in Europe. Proceedings of the National Academy of Sciences 108 (7);
11. Comisia Europeană, Direcția Generală Sănătate și Siguranță Alimentară. Ghid pentru evaluarea starii de sanatate a refugiatilor si migrantilor in UE/SEE, Uniunea Europeana, 2015;

12. Davis J., Lambert R. (2002). Engineering in emergencies: a practical guide for relief workers, $2^{\text {nd }}$ Ed. London, Intermediate Technology Publications;

13. Elizabeth Ferris. Displacement, Natural Disasters, and Human Rights. https://www. brookings.edu/on-the-record/displacementnatural-disasters-and-human-rights/;

14. Fussell E., Lowe S.R. The impact of housing displacement on the mental health of low-income parents after Hurricane Katrina. SocSci Med 2014; 113: 137-44;

15. Gayer M. \& Connolly M.A. Chapter 5: "Communicable Disease Control After Disasters" in Public Health Consequences of Disasters, 2nd edition, eds. Noji, EK. Oxford: Oxford University Press, 2005;

16. Hansen A., Oliver-Smith A., eds. (1982). Involuntary migration and resettlement: the problemsand responses of dislocated peoples. Boulder, CO, Westview;

17. Internal Displacement Monitoring Centre. Global Estimates 2015: People displaced by disasters, IDMC, Geneva, july 2015;

18. International Federation of Red Cross and Red Crescent Societies, Johns Hopkins University (2000). Public health guide for emergencies. Baltimore, MD, The Johns Hopkins University;

19. International Organization for Migration. Key migration terms, http://www.iom.int/ key-migration-terms;

20. Menne B., Murray V. Floods in the WHO European region: health effects and their prevention. Geneva, London: World Health Organisation, Public Health England, 2013. http://www.euro.who.int/_data/assets/pdf_ file/0020/189020/e96853.pdf;

21. Morgan 0 . Infectious disease risks from dead bodies following natural disasters. Pan Am J Public Health 15(5);

22. Munro A., Kovats R.S., Rubin G.J. et al. Effect of evacuation and displacement on the association between flooding and mental health outcomes: a cross-sectional analysis of UK survey data. Lancet Planet Health 2017;
23. Noji E. Public Health Consequences of Disasters. New York, Oxford University Press, 1997.Noji E. Public Health Consequences of Disasters. New York, Oxford University Press, 1997;

24. Office for the Coordination of Humanitarian Affairs. Peru: Situation Report No. 9 http://reliefweb.int/report/peru/rainy-seasonsituation-report-no-09-27-april-2017;

25. Pan American Health Organization. Natural Disasters: Protecting the Public's Health. Washington, Pan American Health Organization Scientific Publication 575, 2000;

26. Shilu Tong. Flooding-related displacement and mental health, planetary-health Vol 1 July 2017; www.thelancet.com;

27. Sobsey M.D. Managing water in the home: accelerated health gains from improved water supply. Geneva, World Health Organization;

28. Sphere Project (2000). The Sphere Project humanitarian charter and minimum standards in disaster response, first final edition. Geneva;

29. Tapsell S.M., Tunstall S.M., Wilson T. Banbury and Kidlington four years after the flood, an examination of the long-term health effects of flooding. Enfield: Flood Hazard Research Centre, Middlesex University, 2003;

30. United Nations Children's Fund (1999). A manual on hygiene promotion. New York, NY(Water, Environment and Sanitation Series, No. 6);

31. United Nations Development Programme, Inter-Agency Procurement Services Office (1995). Emergency relief items, compendium of generic specifications. Vol. 1 , Telecommunications, shelter and housing, water supply, food, sanitation and hygiene, materials handling, power supply; Vol. 2, Medical supplies and equipment, selected essential drugs, guidelines for drug donations. New York, NY;

32. United Nations Environment/OCHA Joint Unit. Flooding assessment. Technical report, Peru, may 2017, Switzerland, 2017;

33. United Nations Environment/OCHA Joint Unit. The environmental emergencies Guidelines, $2^{\text {nd }}$ edition, Switzerland 2017; 
34. United Nations High Commissioner for Refugees. Refugge Health, sept 1995; http://www.unhcr.org/excom/ scaf/3ae68bf424/refugee-health.html;

35. United Nations High Commissioner for Refugees (1997). Vector and pest control in refugeesituations. Geneva;

36. United Nations Office for Disaster Risk Reduction. Sendai Framework for Disaster Risk Reduction 2015-2030, Geneva, 2015;

37. United Nations Reffugee and Migrants. Definitions, http://www.un.org/en/sections/ issues-depth/refugees/index.html;

38. Wisner B., Adams J. Environmental health in emergencies and disasters: a practical guide. World Health Organization 2002;

39. World Health Organization. Climate Change and Health, fact sheet july 2017 , http:// www.who.int/mediacentre/factsheets/fs266/ en;

40. World Health Organization. Disaster - Preparedness and response, http://www. euro.who.int/en/health-topics/emergencies/ disaster-preparedness-and-response/ data-and-statistics;
41. World Health Organization. Environment and health, http://www.euro.who.int/en/ health-topics/environment-and-health/ Climate-change/data-and-statistics;

42. World Health Organization (1991b). Environmental health management in emergencies. Alexandria, WHO Regional Office for the Eastern Mediterranean;

43. World Health Organization. 10 facts on Climate Change and Health http://www. who.int/features/factfiles/climate_change/ facts/en/index9.html;

44. World Health Organization. FLOODS Technical Hazard Sheet - Natural Disaster Profile, http://www.who.int/hac/ techguidance/ems/floods/en/;

45. World Health Organization. Humanitarian Health Action.Flooding and communicable diseases fact sheet; http://www.who.int/hac/ techguidance/ems/flood_cds/en/;

46. World Health Organization (1995b). Hygiene in food service and mass catering establishments. Geneva;

47. World Health Organization, United Nations Environment Programme (1991). Manual on water and sanitation for health in refugee camps. Geneva;

48. World Health Organization (1996a). Mental health of refugees. Geneva;

49. World Health Organization (1999b). Rapid health assessment protocols for emergencies. Geneva;

50. World Health Organization (1991d). The WHO golden rules for safe food preparation. Alexandria, WHO Regional Office for the Eastern Mediterranean;

51. World Health Organization (2000b). The management of nutrition in major emergencies. Geneva;

52. World Health Organization (1995c). Vector control for malaria and other mosquitoborne disease: the report of a WHO Study Group. Geneva (WHO Technical Report Series 857). 